\title{
Sifat Fisik dan Keawetan Kayu Cemara Gunung (Casuarina junghuniana) di Pegunungan Bromo Kabupaten Probolinggo
}

\author{
Physical Characteristics and Durability of Cemara Gunung Wood (Casuarina junghuniana) \\ in Mt. Bromo Probolinggo
}

Galit Gatut Prakosa ${ }^{1}$, Tatag Muttaqin ${ }^{1}$, dan Harjoko ${ }^{1}$

${ }^{1}$ Forestry Department, University of Muhammadiyah Malang, East Java, Indonesia

e-mail: galitgatut@umm.ac.id

\begin{abstract}
Abstrak
Saat ini pasokan kayu dari hutan alam sudah semakin berkurang, namun pemanfaatan jenis kayu yang kurang dikenal masih sangat terbatas. Alternatif pengunaan kayu komersial lainnya dapat dialihkan mengunakan kayu Cemara Gunung. Tujuan dari penelitian ini yaitu mengetahui sifat fisik kayu Cemara Gunung dan mengetahui keawetan kayu Cemara Gunung terhadap pemberian rayap. Metode yang digunakan yaitu mengetahui kadar air, kerapatan, serta pengembangan tebal kayu. Sedangkan untuk uji keawetan kayu pengumpanan tanpa pilihan mengunakan rayap tanah (Macrotermes gilvus) terhadap ketiga sampel kayu dengan mengunakan (SNI) 01-7207-2014 mengenai uji keawetan kayu terhadap organisme perusak kayu. Hasil penelitian menunjukan kadar air dari bagian kayu gubal lebih besar dari kayu teras, berdasarkan uji kerapatan nilai kerapatan tertinggi ada pada kayu teras yaitu $1,24 \mathrm{~g} / \mathrm{cm}^{3}$, kerapatan kayu gubal I dan kayu gubal II hampir sama bekisar $0,81-0,82 \mathrm{~g} / \mathrm{cm}^{3}$. Berdasarkan uji rayap menunjukan rata-rata penurunan bobot pada sampel uji kayu teras $<3,52 \%$ (sangat tahan) kelas I. Untuk uji kayu gubal I dan kayu gubal II (pengawet) kayu tidak berbeda jauh karena masuk dalam kelas tahan $(3,52-7,50)$ (kelas II). Dari ketiga percobaan uji rayap dalam botol, uji 15 hari (botol I) yang paling efektif diikuti botol II dan botol III.
\end{abstract}

Kata kunci : Cemara Gunung, Sifat fisik, dan Keawetan.

\section{Abstract}

Physical Characteristics and Durability of Cemara Gunung Wood (Casuarina junghuniana) in the Mt. Bromo Probolinggo. The purpose of this study is to find out the physical characteristics of Cemara Gunung wood and to know the durability of Cemara Gunung wood toward termite. The using methods were knowing the water content, density, and the development of wood thickness. Meanwhile, the selecting of wood durability test without the selecting of using soil termites (Macrotermes gilvus) against the three wood samples by using (SNI) 01-7207-2014 regarding the durability of wood test towards wood-destroying organisms. The deriving results showed that the moisture content of the sapwood portion was larger than the heartwood, based upon the highest density test on the heartwood, which was $1.24 \mathrm{~g} / \mathrm{cm}^{3}$, the density of sapwood I and sapwood II was almost equal to $0.81-0,82 \mathrm{~g} / \mathrm{cm}^{3}$. The greater the density value, the stronger the wood. The thick development is directly proportional to density, the thick development value of the two treatments is not too high due to hard Cemara Gunung wood. Based on the termite test showed the average weight reduction in the wood core test sample $<3.52 \%$ (very resistant) class I. For testing sapwood, I and sapwood II (preservative) were not much different because it was included in the resistant class $(3,52-$ $7,50)$ (class II). From the three trials of termite in bottles, the 15-day test (the bottle I) was the most effective followed by bottle II and bottle III.

Keywords: Cemara Gunung, Physical Characteristics, Durability. 


\section{PENDAHULUAN}

Penggunaan kayu sebagai kebutuhan manusia sudah menjadi hal yang umum. Kualitas fisik dan keawetan kayu menjadi bagian penting dari kayu untuk mengkonservasi kayu di alam. Kebutuhan kayu yang semakin meningkat diperparah dengan pertambahan penduduk, yang membutuhkan kayu dalam jumlah besar. Peningkatan angka kebutuhan kayu dalam beberapa tahun terakhir, berbanding terbalik dengan angka produksi kayu yang terus mengalami penurunan. Pada tahun 2013, kebutuhan kayu bulat Indonesia sekitar 39 juta $\mathrm{m}^{3}$ sementara hutan produksi Indonesia hanya mampu menyediakan sekitar 14 juta $\mathrm{m}^{3}$ (Kementrian Perindustrian, 2013). Kecenderungan akan penggunaan kayu saat ini semakin meningkat, baik untuk keperluan bahan bangunan maupun industri. Hal ini perlu diimbangi dengan pengetahuan jenis kayu dan sifatnya, agar kayu tersebut dapat digunakan secara efektif dan efesien (Lempang, 2014).

Saat ini pasokan kayu komersial dari hutan alam sudah semakin berkurang. Permasalahan kurangnya persediaan kayu komersial sebenarnya dapat diselesaikan dengan menebang pohon sesuai dengan kebutuhan yang diinginkan. Tindakan tersebut dapat mengakibatkan pemanenan yang tidak terkontrol dan memicu terjadinya illegal loging, sehingga meningkatkan kemungkinan terjadinya kerusakan lingkungan. Terdapat 3124 jenis kayu di Indonesia yang terdiri dari kayu komersial, non komersial, tidak dikenal, maupun jenis kayu budidaya. Diperkirakan masih banyak jenis jenis kayu tropis yang berpeluang untuk dimanfaatkan dan dikembangkan (Dwianto et al. 2008).

Dalam kehidupan sehari-hari, kayu merupakan bahan yang sangat sering dipergunakan untuk penggunaan alat kebutuhan. Terkadang sebagai barang dalam bentuk padat, kayu tidak dapat digantikan dengan bahan lain karena sifat khasnya. Sebagai pengguna dari kayu yang setiap jenisnya mempunyai sifat-sifat yang berbeda, perlu mengenal sifat-sifat kayu tersebut. Pemilihan atau penentuan jenis kayu untuk tujuan penggunaan tertentu harus betul-betul sesuai dengan yang diinginkan.

Keterbatasan bahan baku kayu baik untuk konstruksi maupun non konstruksi, khususnya yang berasal dari hutan tropis perlu segera diatasi. Salah satunya dengan upaya diversifikasi bahan dengan melakukan pemanfaatan jenis-jenis kayu yang belum banyak dikenal, namun memiliki potensi yang besar dan memiliki sifat kayu yang unggul. Kayu dari hutan 
tanaman maupun hutan rakyat saat ini memiliki keterbatasan, diantarannya ukuran diameter yang kecil. Ukuran diameter yang kecil dikarenakan rotasi penebangan yang lebih singkat, sehingga menghasilkan kayu yang bermutu kurang baik. Rotasi penebangan yang lebih singkat menyebabkan kayu sebagai bahan alamiah berupa balok atau log bukan produk yang efesien sebagai komponen struktural (Purwaningsih, 2014).

Hal yang mendasari penelitian ini adalah bahwa sampai saat ini pemanfaatan jenis kayu yang tergolong kurang dikenal masih sangat terbatas. Ribuan jenis kayu lainnya belum dimanfaatkan dengan baik. Selain itu, kayu-kayu yang belum diketahui secara luas penggunaannya cenderung diabaikan karena kekawatiran akan kualitas kayu tersebut selama pemakaiannya. Salah satu dari kayu yang kurang dikenal adalah kayu Cemara Gunung. Kayu Cemara Gunung di alternatifkan untuk mengantikan pasokan kayu komersial lain yang semakin berkurang.

Cemara Gunung merupakan salah satu jenis tanaman fast growing (cepat tumbuh). Kegunaan lain dari tanaman ini yaitu sebagai sumber energi, khususnya kayu bakar. Kayu ini merupakan sumber energi dominan bagi masyarakat pedesaan yang pada umumnya berpenghasilan rendah. Menurut Departemen Ekonomi Sumber Daya Manusia 2005, 80\% sumber energi masyarakat pedesaan diperoleh dari kayu bakar, khususunya untuk memasak. Penggunaan kayu Cemara Gunung masih terbatas secara lokal untuk bahan bakar dan kayu arang. Dalam upaya peningkatan nilai guna dan pengoptimalan penggunaan kayu, teknologi dan rekayasa dalam bidang perkayuan sangatlah penting. Dalam pemilihan kayu yang baik sifat fisik atau keawetan kayu merupakan hal yang penting. Faktor ini diperlukan karena kayu akan digunakan untuk menahan beban dengan aman dalam jangka waktu yang telah ditentukan. Oleh karena itu, pemanfaatan kayu Cemara Gunung untuk pengolahan kayu memerlukan pemahaman terhadap sifat-sifat penting dari kayu tersebut sehingga kayu dapat dimanfaatkan secara maksimal.

Tujuan dari penelitian ini dalah sebagai berikut :

1. Untuk mengetahui sifat fisik kayu Cemara Gunung agar dapat dimanfaatkan secara tepat

2. Untuk mengetahui kayu Cemara Gunung terhadap pemberian rayap atau serangan rayap berdasarkan uji laboratorium. 
Hasil dari penelitian ini diharapkan dapat memberikan informasi yang lengkap mengenai sifat fisik serta menjadi informasi sifat keawetan kayu cemara gunung, dengan diketahuinya sifat keawetan kayu akan membantu pengguna terkait pemanfaatan-nya.

\section{METODE PENELITIAN}

Penelitian dilaksanakan pada bulan Februari 2018 hingga bulan Mei 2018 di Pegunungan Bromo Kabupaten Probolinggo sementara tempat pelaksanaan pengujian sifat fisik dan keawetan kayu cemara gunung dilaksanakan di Laboratorium Kehutanan Universitas Muhammadiyah Malang.

\section{Bahan dan Alat}

Bahan baku yang digunakan dalam penelitian ini adalah pohon cemara gunung. Bagian pohon yang digukan adalah batang pohon cemara gunung dengan mengambil kayu teras dan gubal gubal I dan kayu gubal II. Sedangkan bahan yang digunakan untuk pengujian keawetan yaitu Rayap Tanah (macrotermes gilvus), air, tanah, dan pasir. Alat- alat yang digunakan antara lain oven, timbangan analitik, gergaji, palu, penggaris, jangka sorong, ember plastik, botol uji, aluminium foil, kertas milimeter block, kamera, dan alat tulis.

\section{Prosedur Penelitian}

\section{Pengujian Sifat Fisik}

Contoh uji kayu untuk uji sifat fisik di potong $2 \mathrm{~cm} \mathrm{x} 2 \mathrm{~cm} \mathrm{x} 2 \mathrm{~cm}$ sebanyak 27 contoh uji Semua contoh uji dikeringkan dalam oven pada suhu $103^{\circ} \mathrm{C} \pm 2^{\circ} \mathrm{C}$, hingga beratnya konstan kemudian ditimbang dan diukur volumenya sehingga diperoleh berat kering oven dan volume kering oven. Kadar air segar, kadar air kering udara, kerapatan kering oven, dan berat jenis kayu cemara

1. Kadar air

Caranya menyiapkan Contoh uji yang digunakan dalam pengujian kadar air yakni memotong $2 \times 2 \mathrm{~cm}$ selanjutanya Contoh uji ditimbang untuk mengetahui berat awal dengan ketelitian hingga 0,1 gram. Contoh uji dikeringkan dalam oven pada suhu $103^{\circ} \mathrm{C} \pm 2^{\circ} \mathrm{C}$ kegitan ini diulang selang waktu 6 jam sampai bertnya konsntan (berat kering mutlak), yaitu bila perbedaan beratnya maksimum $0,1 \%$. Kadar air dihiung mengunakan rumus :

Kadar air $(\%)=\frac{B a-B k}{B k} \times 100 \%$

$\mathrm{Ba}$ : berat awal (gram)

$\mathrm{Bk}$ : berat kering mutlak (gram)

\section{Kerapatan}

Menyiapkan contoh uji kerapatan dengan ukuran $2 \times 2 \mathrm{~cm}$. Contoh uji diukur panjangnya pada kedua sisi lebarnya, 25 $\mathrm{mm}$ dari tepi dengan ketelitian 0,1 $\mathrm{mm}$. Mengukur lebarnya pada kedua sisi 
panjangnya, $2 \mathrm{~cm}$ dari tepi dengan ketelitian $0,1 \mathrm{~mm}$ selanjutnya mengukur tebalnya pada keempat sudutnya, $25 \mathrm{~mm}$ dari sudutnya (pada titik persilangan pengukuran panjang dan lebar) dengan ketelitian 0,05 $\mathrm{mm}$. Contoh uji ditimbang dengan ketelitian 0,1 gram.

Kerapatan kayu dihitung dengan mengunakan rumus :

Kerapatan $\left(\right.$ gram $\left./ \mathrm{cm}^{3}\right)=\frac{B}{I}$, dengan

B : berat kayu (gram)

I : volume $\left(\mathrm{cm}^{3}\right)=$ panjang $(\mathrm{cm}) \mathrm{x}$ lebar $(\mathrm{cm}) \mathrm{x}$ tinggi $(\mathrm{cm})$

3. Pengembangan tebal setelah direndam air

Pengujian permeabilitas kayu dilakukan dengan memotong contoh uji kayu berukuran 2 x $2 \mathrm{~cm}$. Contoh uji diukur tebalnya pada bagian pusatnya dengan ketelitian $0,05 \mathrm{~mm}$. Selanjutnya merendam contoh uji dengan air pada suhu $25^{\circ} \mathrm{C} \pm 1^{\circ} \mathrm{C}$, sekitar $3 \mathrm{~cm}$ dari permukaan air selama \pm 24 jam dan direndam juga 72 jam. Kemudian menggangkat contoh uji, diseka dengan kain dan diukur tebalnya.

Pengukuran pengembangan tebal setelah direndam air dapat dihitung mengunkan rumus :

Pengembangan tebal $(\%)=\frac{T 2-T 1}{T 1} \times 100 \%$

T1 : tebal awal sebelum direndam air $(\mathrm{cm})$

$\mathrm{T} 2$ : tebal awal setelah direndam air $(\mathrm{cm})$

\section{Pengujian Keawetan Kayu Terhadap Serangan Rayap}

Pengujian keawetan kayu cemara gunung dilakukan dengan mengunakan metode berdasarkan pengujian mengunakan metode Standar Nasional Indonesia (SNI) 01-7207-2014 mengenai uji keawetan kayu dan produk kayu terhadap organisme perusak kayu yang telah dimodifiksi berdasarkan penelitian Ariana et al. (2010). Dalam penelitian ini organisme perusak kayu yang dimaksud adalah rayap tanah.

Caranya : memotong contoh uji berupa balok kecil tipis dibuat dengan ukuran $(2.00 \times 2.00 \times 2.00) \mathrm{cm}^{3}$. Sebelum diumpankan ke rayap terlebih dahulu seluruh contoh uji dikeringkan menggunakan oven pada suhu $(103 \pm 2)^{\circ} \mathrm{C}$ selama 24 jam atau sampai berat kering mutlak, selanjutya menimbang contoh uji untuk menentukan berat awalnya. Selanjutnya contoh uji dimasukan ke dalam botol uji sedemikian rupa sehingga salah satu bidang contoh uji menyentuh dinding botol uji. Kemudian dalam botol uji memasukan pasir steril 200 gram lalu ditambahkan air mineral sebanyak $50 \mathrm{ml}$. Sebanyak 200 ekor rayap tanah (Macrotermes gilvus yang masih sehat dan aktif (setiap 1 minggu sekali penambahan rayap pada botol uji) dimasukan ke dalam 
botol uji selanjutnya botol uji ditutup aluminium foil dan disimpan dalam ruang gelap selama 6 minggu.

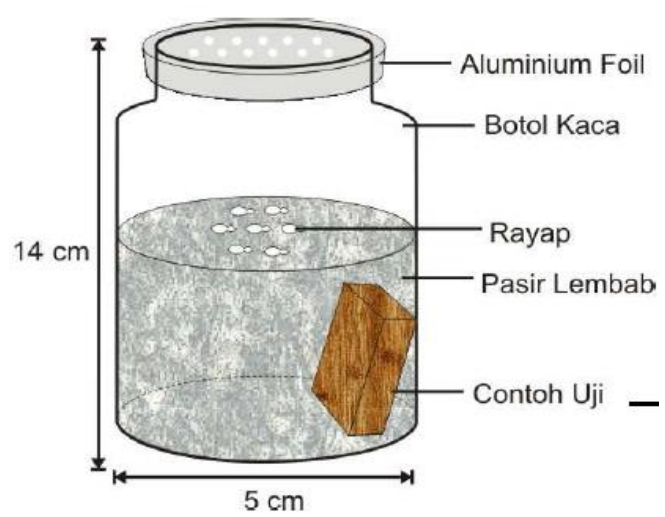

Gambar 1. Contoh pengujian dengan mengunakan rayap tanah dengan metode SNI 01-72072014.

Setelah 6 minggu pengujian, mengelurkan contoh uji dari botol lalu membersihkan pasir dan tanah yang melekat. Contoh uji dioven pada suhu $(103 \pm 2)^{\circ} \mathrm{C} \quad$ selama 24 jam untuk mendapatkan berat akhir (W2). Nilai kehilangan berat contoh uji akibat serangan rayap dihitung dengan persamaan berikut sesuai dengan penelitian Arinana et al. (2010) :

$$
\mathrm{P}=\frac{\mathrm{W}_{1}-\mathrm{W}_{2}}{\mathrm{~W}_{1}} \times 100 \%
$$

Keterangan :

$\mathrm{P}:$ Penurunan berat (\%)

$\mathrm{W}_{1}$ : Berat kering oven kayu sebelum diumpan $(\mathrm{g})$

$\mathrm{W}_{2}$ : Berat kering oven kayu setelah diumpan $(\mathrm{g})$
Lalu menimbang bobot akhir contoh uji dalam kondisi kering oven dan menentukan penurunan bobot untuk mengetahui kelas ketahanan kayu terhadap rayap tanah.

Teknik analisis data menggunakan aplikasi SPSS 2,1 yakni dengan cara menginstal hasil pengujian ke dalam SPSS, kemudian diuji korelasi yaitu uji hubungan antara perlakuan dan waktu pengumpanan pada rayap.

\section{HASILDAN PEMBAHASAN}

\section{Deskripsi Kayu Cemara Gunung}

Jenis kayu yang kurang dikenal, salah satunya adalah kayu cemara gunung karena terletak didaerah tropis (Pegunungan Tengger). Kayu ini merupakan salah satu kayu yang keras dan merupakan kayu andalan masyarakat suku Tengger. Pada masyarakat suku Tengger, kayu ini digunakan untuk bahan bangunan salah satunya yaitu untuk atap rumah suku Tengger. Serpihan, ranting dari kayu ini juga dijadikan kayu bakar yang menurut penuturan tokoh adat setempat, merupakan kayu bakar yang tahan lama.

Berdasarkan hal tersebut, maka dicoba melakukan penelitian sifat fisis dan keawetan kayu. 


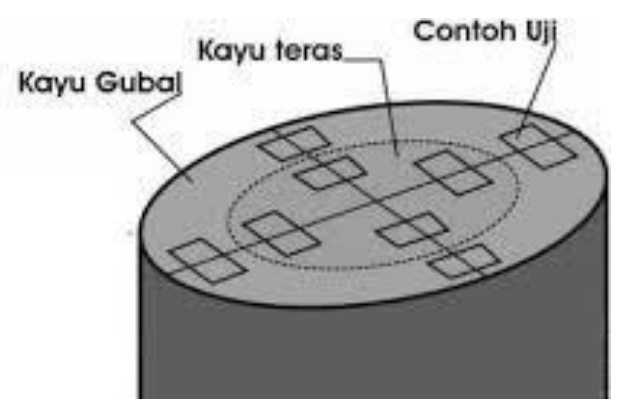

Gambar 2. Gambar bagan contoh pemotongan kayu

Adapun gambar ilustrasi pengambilan sampel kayu yang dilakukan dalam penelitian ini seperti gambar diatas. Pembagian jenis kayu pada penelitian ini dengan mengambil 2 bagian secara balok yaitu pada batang kayu Cemara Gunung, terdiri dari kayu gubal dan kayu teras yang menjadi bahan pengujian sifat fisik dan keawetan kayu.

\section{Sifat Fisik}

Sifat fisik adalah karakteristik kuantitatif dan ketahanan dari pengaruh lingkungan. Sifat fisik yang penting diperhatikan dari kayu diantaranya adalah kadar air, berat jenis, dan kerapatan (Bowyer et al. 2003).

\section{Kadar Air Kayu Cemara Gunung}

Menurut Bowyer 2003, kadar air didefinisikan sebagai persentase air yang terkandung dalam kayu. Pada kayu segar kadar air (KA) bisa sampai $100 \%$, air mengisi dinding sel, sebagian rongga sel (sekitar 50\% rongga sel berisi air bebas) dan uap air di bagian rongga sel yang kosong, Kandungan diketahui dapat mempengaruhi karakteristik dari kayu seperti berat dan kekuatan.

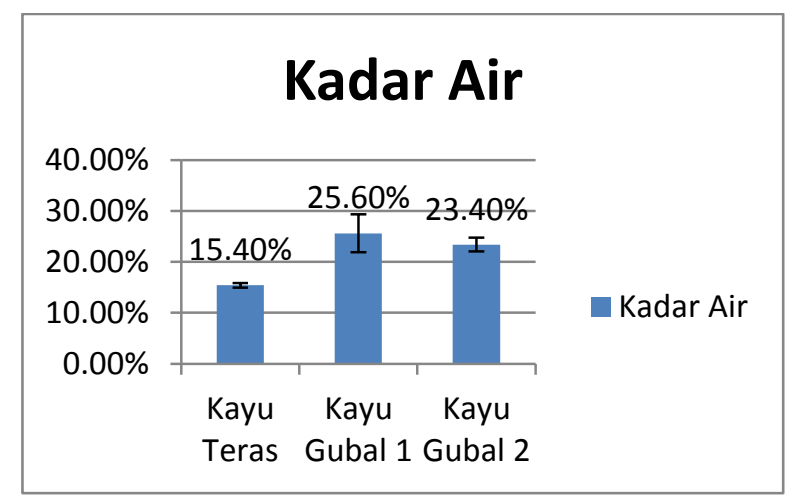

Gambar 3. Grafik rata- rata hasil uji kadar air kayu teras dan kayu gubal

Setelah proses pengeringan oven, bagian kayu teras cemara gunung mengalami penurunan berat yang paling besar, kemudian bagian kayu gubal I dan kayu gubal II. Kadar air kayu antara posisi kayu teras dan kayu gubal pada pohon cemara berbeda, dimana kadar air dari bagian kayu gubal lebih besar dari bagian kayu teras. Nilai kadar air kayu Cemara Gunung dapat dilihat pada grafik diatas bahwa nilai tertinggi kadar air terdapat pada kayu gubal I yaitu $25,6 \%$ dan nilai terendahterdapat pada bagian kayu teras dengan nilai $15,4 \%$. Kadar air dari bagian gubal pohon cemara gunung berkisar antara $23,4 \%$ - 35,3\%. Kadar air dari bagian gubal besar dari pada bagian teras pohon cemara gunung. Siarudin dan Marsoem (2007) menyatakan bahwa gubal pohon memiliki kadar air tertinggi, diduga 
hal ini disebabkan oleh besarnya rongga sel pada bagian gubal memiliki kerapatan terendah. Kayu teras umumnya hanya mempunyai perbedaan kecil dalam kandungan air antara kayu gubal dan kayu teras. Kandungan air kayu gubal biasanya jauh lebih tinggi dari pada kayu teras.

\section{Kerapatan Kayu Cemara Gunung}

Kerapatan kayu berhubungan dengan kadar air, dimana kayu dengan kadar air yang besar umumnya mempunyai kerapatan yang lebih rendah (Kasmudjo, 2010). Berat suatu jenis kayu tergantung dari jumlah zat kayu yang tersusun, rongga selnya, kadar air yang terkandung didalamnya. Berat kayu juga dipengaruhi oleh banyaknya pori dalam kayu.

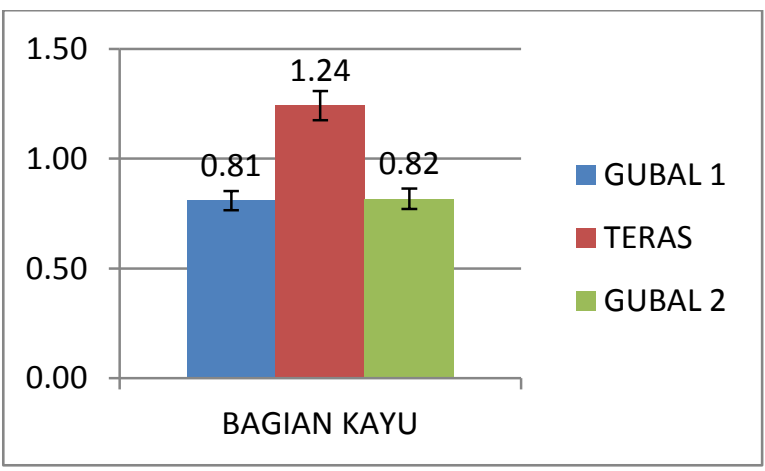

Gambar 4. Grafik hasil uji rata-rata keratan

Berdasarkan hasil pengujian kerapatan diperoleh nilai kerapatan tertinggi ada pada kayu teras yaitu 1,24 $\mathrm{g} / \mathrm{cm}^{3}$, untuk nilai rata rata kayu gubal sebesar 0,81 g/cm3. Sedangkan untuk nilai rata rata kayu gubal 2 yaitu $0,82 \mathrm{~g} / \mathrm{cm} 3$. Nilai rata rata antara kayu gubal I dan kayu gubal II hampir sama atau tidak berbeda jauh, dikarekan kandungan yang ada di dalam kayu teras lebih besar dari pada kayu gubal. Kerapatan merupakan suatu sifat fisis yang sangat penting terhadap kekuatan kayu, biasanya semakin besar nilai kerapatan maka semakin kuat kayu tersebut.

\section{Pengembangan Tebal}

Pengembangan tebal berbanding lurus dengan kerapatan dari hasil tabel diatas menunjukan nilai pengembangan tebal dari kedua perlakuan tidak terlalu tinggi dikarenakan kayu Cemara Gunung keras.

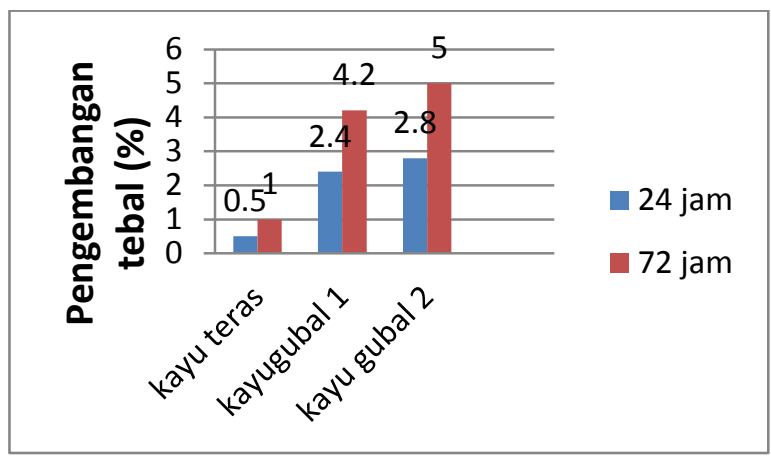

Gambar 5. Grafik rata-rata hasil uji pengembangan tebal.

Grafik diatas menunjukkan nilai pengembangan kayu cemara ( 24 x 1 jam) dan (24 x 3 jam) mengalami peningkatan mulai dari bagian kayu teras sampai kayu gubal. Kadar air yang berbeda terjadi akibat perbedaan kemampuan absorbsi air pada kayu. Absorbsi air oleh kayu dipengaruhi oleh susunan sel yang berbeda pada masing-masing arah, volume rongga sel, ukuran pori dan kemampuan air 
menembus rongga-rongga pori. Kemampuan kayu semakin berkurang untuk menyerap air dipengaruhi oleh kerapatan kayu. Semakin tinggi kerapatan maka sifat pengembangan tebal kayu cenderung semakin meningkat.

\section{Pengujian Keawetan Kayu Terhadap Serangan Rayap}

Keawetan kayu cemara gunung dinilai berdasarkan klasifikasi SNI (2014) yang dilihat berdasarkan penurunan bobot kayu yang dihasilkan selama pengujian terhadap rayap

Tabel 1. Klasifikasi keawetan kayu berdasarkan SNI 2014.

\begin{tabular}{llc}
\hline Kelas & Keawetan & $\begin{array}{c}\text { Penurunan } \\
\text { Berat }(\%)\end{array}$ \\
\hline I & Sangat Tahan & $<3,52$ \\
II & Tahan & $3,52-7,50$ \\
III & Sedang & $7,50-10,96$ \\
IV & Buruk & $10,96-18,94$ \\
V & Sangat buruk & $18,94-31,89$ \\
\hline
\end{tabular}

Adanya serangan rayap tanah ditandai dengan pengotoran permukaan kayu dengan bekas tanah yang masih menempel.

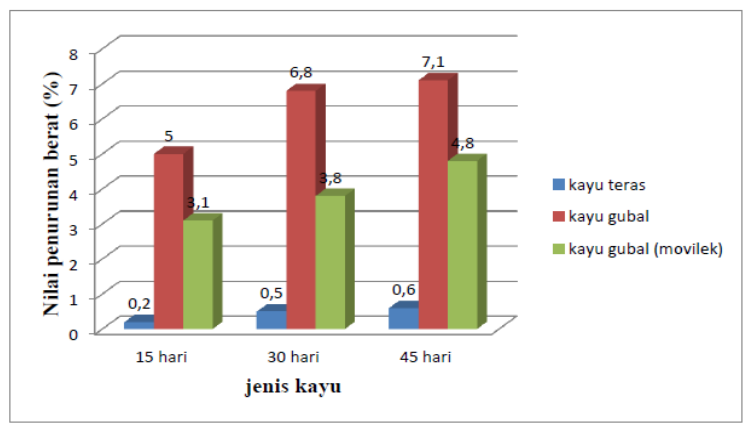

Gambar 6. Rata-rata penurunan berat.
Tabel diatas menunjukan rata-rata penurunan bobot pada setiap sampel uji kayu teras $<3,52 \%$ (sangat tahan rayap). Untuk contok uji kayu gubal I dan kayu gubal II (pengawet) kayu tidak berbeda jauh karena masih masuk dalam kelas tahan berkisar $(3,52-7,50)$ yang kemudian diklasifikasikan tahan. Kayu Cemara Gunung termasuk kayu dalam kelas awet I dan II, kelas keawetan kayu tersebut selanjutnya berpengaruh pada bagaimana pengolahan kayu selanjutnya terutama pada hal penggunaannya.

\section{Penurunan Bobot Contoh Uji}

Penurunan bobot contoh uji merupakan rata-rata berat akhir kering tanur yang dihasilkan setelah pengujian kemudian menjadi penentuan kelas awet dan kelas ketahan kayu cemara gunung. Dari gambar ditas penurunan bobot tertinggi ada pada kayu gubal I yang tidak diberi perlakuan. Menurunnya persentase kehilangan berat pada kayu teras sedikit dikarenakan kayu teras mengandung zat akstraktif yang tinggi. Kuswantoro 2005, menyatakan semakin tinggi kandungan ekstraktif kayu maka kayu akan semakin awet terhadap serangga perusak kayu utamanya serangga. Dari hasil ditas kayu cemara gunung termasuk dalam kelas awet I dan II maka kegunaan kayu cemara gunung digunakan untuk membuat galih 
(tiang) rumah, atap rumah atau kontruksi dan alat musik.

\section{Intensitas Serangan Rayap}

Intensitas serangan rayap diukur berdasarkan derajat kerusakan kayu dan penuruanan bobot selama 15 hari, 30 hari dan 45 hari. Pengamatan intensitas rayap dilakukan untuk melihat seberapa besarkerusakan fisik yang ditimbulkan oleh rayap tanah selama uji berlangsung. Serangan rayap bisa dilihat dari bekas gigitan pada permukaan kayu Cemara Gunung.

Tabel 2. Intensitas serangan rayap

\begin{tabular}{|c|c|c|c|c|}
\hline $\begin{array}{l}\text { Letak dalam } \\
\text { batang }\end{array}$ & $\begin{array}{l}\text { Rata-rata } \\
\text { penurunan } \\
\text { bobot } \\
\text { sampel \% }\end{array}$ & $\begin{array}{l}\text { Derajat } \\
\text { kerusakan kayu }\end{array}$ & Ketahanan & $\begin{array}{l}\text { Waktu dalam } \\
\text { botol }\end{array}$ \\
\hline $\begin{array}{l}\text { Kayu teras } \\
\text { Kayu gubal } 1 \\
\begin{array}{l}\text { Kayu gubal } 2 \\
\text { (movilek) }\end{array}\end{array}$ & \begin{tabular}{l|}
$0,2 \%$ \\
$5,0 \%$ \\
$3,3 \%$ \\
\end{tabular} & $\begin{array}{l}\text { Utuh } \\
\text { Utuh } \\
\text { Utuh }\end{array}$ & $\begin{array}{l}\text { Sangat tahan } \\
\text { Sangat tahan } \\
\text { Sangat tahan }\end{array}$ & 15 hari \\
\hline $\begin{array}{l}\text { Kayu teras } \\
\text { Kayu gubal } 1 \\
\begin{array}{l}\text { Kayu gubal } 2 \\
\text { (movilek) }\end{array}\end{array}$ & $\begin{array}{l}0,5 \% \\
6,8 \% \\
3,8 \% \\
\end{array}$ & $\begin{array}{l}\text { Utuh } \\
\text { Serangan } \\
\text { ringan } \\
\text { Utuh }\end{array}$ & $\begin{array}{l}\text { Sangat tahan } \\
\text { Tahan } \\
\text { Sangat tahan }\end{array}$ & 30 hari \\
\hline $\begin{array}{l}\text { Kayu teras } \\
\text { Kayu gubal } 1 \\
\begin{array}{l}\text { Kayu gubal } 2 \\
\text { (movilek) }\end{array}\end{array}$ & \begin{tabular}{l|}
$0,6 \%$ \\
$7,1 \%$ \\
$4,8 \%$ \\
\end{tabular} & $\begin{array}{l}\text { Utuh } \\
\text { Serangan } \\
\text { ringan } \\
\text { Utuh }\end{array}$ & $\begin{array}{l}\text { Sangat tahan } \\
\text { Tahan } \\
\text { Sangat tahan }\end{array}$ & 45 hari \\
\hline
\end{tabular}

Berdasarkan uji rayap yang telah dilakukan menunjukan serangan rayap ringan hingga masih ada sampel yang utuh dengan nilai rata rata $<5 \%$. Hal ini dikarenakan oleh kandungan zat ektraktif yang ada pada kayu teras termasuk tinggi kemudian menyebabkan intensitas rayap sangat rendah.

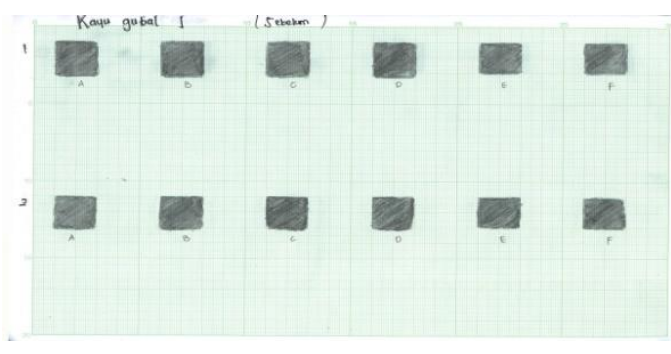

Gambar 7. sebelum diumpai rayap

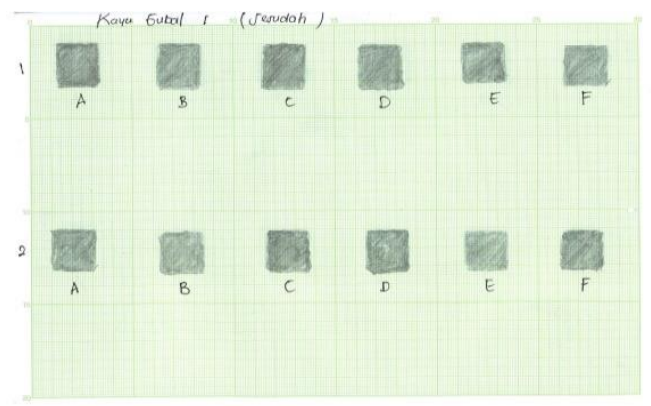

Gambar 8. Sesudah diumpani rayap

Gambar diatas merupakan hasil aksiran dari perlakuan kayu sebelum dan sesudah diumpankan kedalam rayap tanah. sehingga hasil yang diperoleh dapat menjadi acuan dalam penentuan besar kecilnya aktifitas serangan rayap dan keawetan kayu selama pengujian. Dari perlakuan 15 hari, 30 hari, dan 45 hari dilakukan pengujian diperoleh bekas gigitan ringan pada permukaan sampel uji pada kayu namun secara dominan hanya terjadi pada bagian gubal I yang tidak diberi perlakuan, sedangkan pada kayu teras dan kayu gubal II (pengawet) tidak terjadi kerusakan yang begitu besar. Daya makan rayap sedikit dikarenakan Pada alam rayap bebas memilih sendiri lingkungan yang paling sesuai bagi hidupnya. Sedangkan dilaboratorium, rayap dipaksa makan, Maka dari itu setiap 
6-7 hari melakukan penambahan rayap pada botol uji.

\section{Analisa analisa corelasi statistik perlakuan dan penurunan berat pada kayu Cemara Gunung}

Terlihat pada output bahwa probabilitas antara Perlakuan 1 dengan perlakuan 2 memiliki nilai $=0,89>0,05$ berdasarkan syarat probabilitas maka $\mathrm{H}_{0}$ diterima yang berarti terdapat hubungan antara perlakuan 1 dan perlakuan 2 yang kuat.

Tabel 3. analisa correlationas

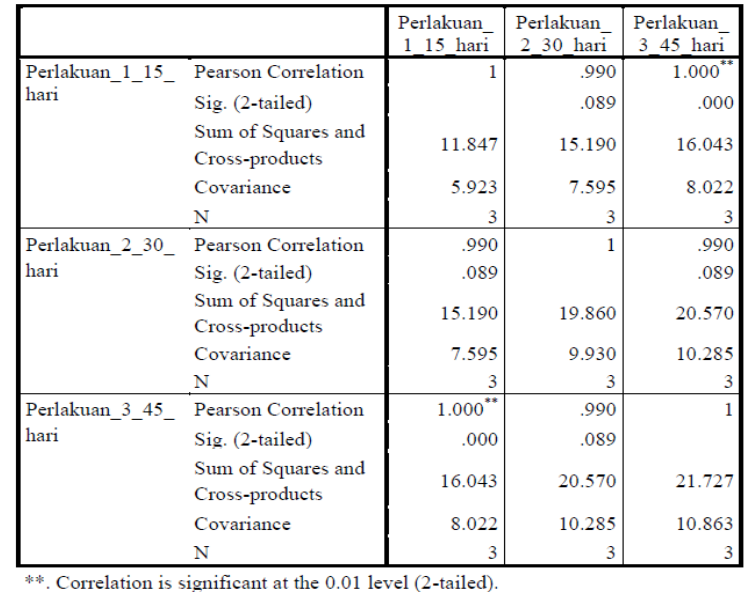

Perlakuan 1 dengan perlakuan 3 memiliki nilai $=0,00<0,05$ berdasarkan syarat probabilitas maka $\mathrm{H}_{0}$ ditolak yang berarti tidak terdapat hubungan antara perlakuan 1 dan perlakuan 3 yang memiliki hubungan lemah. Perlakuan 2 dengan perlakuan 3 memiliki nilai $=0,89>0,05$ berdasarkan syarat probabilitas maka $\mathrm{H}_{0}$ diterima yang berarti terdapat hubungan antara perlakuan 2 dan perlakuan 3 yang kuat. Berdasarkan tabel diatas dapat dilihat bahwa perlakuan yang paling efektif adalah perlakuan 1 (15 hari) atau perlakuan uji botol 15 hari dikarenaan daya makan rayap lebih sedikit dibanding perlakuan botol 2 dan botol 3 .

\section{KESIMPULAN DAN SARAN}

\section{Kesimpulan}

Pengujian sifat fisik kayu pada bagian kayu gubal kadar air lebih besar dari bagian kayu teras. Kayu teras mempunyai kerapatan tertinggi, semakin besar kerapatan maka kayu semakin kuat. Nilai pengembangan tebal dari kedua perlakuan tidak terlalu tinggi dikarenakan kayu cemara gunung keras. Hasil uji rayap menunjukan rata-rata penurunan bobot kayu teras $<3,52 \%$ sangat tahan (kelas I) . Kayu gubal I dan kayu gubal II (pengawet) kelas keaewetan kayu masuk dalam kelas tahan $(3,52-7,50)$ atau kelas II. Oleh karena itu Cemara Gunung termasuk kayu dalam kelas awet I dan II, penggunaan kayu Cemara Gunung cocok untuk kontruksi atap, lantai (parket), bahan baku mebel dan alat musik.

\section{Saran}

Perlu adanya penelitian lebih lanjut tentang zat ekstraktif yang terkandung dalam kayu Cemara Gunung sehingga 
dapat mengetahui pengaruh terhadap keawetan alami kayu.

\section{DAFTAR PUSTAKA}

Arinana, Simamora L, Tsunoda K, Hadi YS, Herliyana EN. 2010. Comparison of Indonesian and Japanese Standardized Test Using Subterranean Termitesin the Laboratory. IWoRS 2010:603.

Bowyer J.L., Shmulsky R., and Haygreen J.G. 2003. Forest Products and Wood Science An Introduction Fourth Edition. IOWA (US): IOWA State University Pr.

Departemen ESDM. 2005. Blueprint Pengelolaan Energi Nasional 2005 - 2025. Jakarta.

Dwianto W. dan Marsoem S.N. 2008. Tinjauan Hasil- Hasil Faktor-faktor Alam Yang Mempengaruhi Sifat Fisik dan Mekanik Kayu Indonesia. Journal Tropical Wood Science and Technology. 6(2): 85-100.

Kasmudjo. 2010. Teknologi Hasil Hutan. Cakrawala Media. Yogyakarta.

Kementrian Perindustrian. 2013. Kebutuhan Kayu Bulat 2003 2013. Jakarta (ID): Direktorat Jenderal Industri Agro.

Kuswantoro DP. 2005. Keawetan, deteriorisasi, dan pengawetan kayu rakyat. AlBasia 2(1): 48-55.

Lempang, M. 2014. Sifat Dasar dan Potensi Kegunaan Jabon Merah. Jurnal Penelitian Kehutanan Wallacea. (2):163- 175.

Purwaningsih E.D. 2014. Laporan Akhir Ilmu Kayu. Program Studi Kehutanan. Universitas Mataram.

Siarudin, M. dan S. N. Marsoem. 2007. Karakteristik Dan Variasi Sifat Fisik Kayu Mangium (Acacia mangium Willd.) Pada Beberapa Jarak Tanam Dan Kedudukan
Aksial-Radial. Jurnal Pemuliaan Tanaman Hutan, 1(1):1-11. 